DOI : $10.14746 / \mathrm{pp} .2015 .20 .4 .5$

Przemysław OSIEWICZ

Poznań

\title{
Przyczyny oraz przebieg procesu zmian politycznych w Egipcie w latach 2011-2014
}

\begin{abstract}
Streszczenie: Proces zmian politycznych w Egipcie po 2011 roku zyskal szczególne znaczenie w ramach szerszego procesu zmian w ramach świata arabskiego - tak zwanej arabskiej wiosny. Kairski plac Tahrir stał się najważniejszym symbolem zmian nie tylko w wymiarze wewnętrznym, ale także regionalnym. Sukces Egipcjan stał się źródłem inspiracji dla innych arabskich społeczeństw, rządzonych przez autorytarnych przywódców, na przykład, w Syrii, Jemenie, Libii i Bahrajnie. W tym kontekście ważna jest odpowiedź na pytanie, jakie czynniki społeczne, polityczne i ekonomiczne doprowadzily do tak naglej zmiany politycznej w Egipcie. Ponadto, czy doszlo do rzeczywistej wymiany elity rządzącej. czy też wydarzenia z 2011 roku byly w dużej mierze inspirowane przez najbliższe otoczenie prezydenta Hosni Mubaraka i tym samym stanowily jedynie przejaw wewnętrznej rywalizacji w ramach armii oraz reżimowej Partii Narodowo-Demokratycznej (NDP).
\end{abstract}

Słowa kluczowe: Egipt, arabska wiosna, egipska rewolucja, plac Tahrir, Kefaya

\section{Wprowadzenie}

D rzesilenia polityczne w Egipcie w 2011 oraz 2013 roku stanowity najistotniejszy element całego procesu zmian polityczno-społecznych w państwach arabskich Afryki Północnej i Bliskiego Wschodu. Szczególne, symboliczne znaczenie dla samych Egipcjan oraz obywateli innych państw arabskich miało odsunięcie od władzy wpływowego prezydenta Hosni Mubaraka w lutym 2011 roku. Zwycięstwo demonstrantów z placu Tahrir zyskało zatem znaczenie nie tylko w wymiarze wewnętrznym, ale także regionalnym. Bez wątpienia sukces Egipcjan stanowił zachętę dla społeczeństw w innych rządzonych autorytarnie państwach arabskich, na przykład, w Syrii, Libii i Jemenie.

W tym kontekście ważna jest odpowiedź na pytanie, jakie czynniki społeczne, polityczne i ekonomiczne doprowadziły do tak nagłej zmiany politycznej w Egipcie. I czy naprawdę, z perspektywy roku 2015, doszło do wymiany elity rządzącej, czy też wydarzenia z 2011 roku były w dużej mierze inspirowane przez najbliższe otoczenie prezydenta Mubaraka i tym samym stanowiły jedynie przejaw wewnętrznej rywalizacji w ramach armii oraz reżimowej Partii Narodowo-Demokratycznej (NDP).

Celem niniejszego artykułu jest znalezienie odpowiedzi na powyższe pytania, na podstawie pogłębionej analizy przyczyn oraz przebiegu zmian politycznych w Egipcie w latach 2011-2014. Cezurę początkową wyznacza rozpoczęcie protestów na placu Tahrir w styczniu 2011 roku, natomiast końcową wybór Abd al-Fattaha as-Sisiego na prezydenta Egiptu. W tym kontekście szczególne znaczenie zyskuje analiza przesilenia politycznego w lipcu 2013 r., w wyniku którego od władzy zostali odsunięci przedstawiciele 
Bractwa Muzułmańskiego, na czele z prezydentem Muhammadem Mursim. Przedmiot badawczy stanowią zarówno przyczyny o charakterze politycznym, jak i gospodarczym oraz społecznym.

\section{Zarys sytuacji spoleczno-politycznej w Egipcie za rządów Hosni Mubaraka}

Wydarzenia na placu Tahrir z przełomu stycznia i lutego 2011 roku miały swoje źródła także w wydarzeniach sprzed blisko pięćdziesięciu lat. W 1952 roku grupa Wolnych Oficerów zmusiła do abdykacji i wyjazdu z państwa króla Egiptu - Faruka. Faruk abdykował na rzecz swojego syna - Fuada II. Rok później proklamowano republikę, zniesiono Radę Regencyjną, a na czele państwa stanął prezydent Muhammad Nagib. W wyniku tych wydarzeń system polityczny Egiptu uległ zasadniczej zmianie, ponieważ, jak słusznie wskazał Afaf Lufti as-Sajjid Marsot, „po raz pierwszy od ponad dwóch tysięcy lat, od czasów faraonów, Egipt był rządzony przez Egipcjan. Turecko-czerkieska monarchia, podtrzymywana i umacniana dzięki wojskom brytyjskim, przeminęła" (Marsot, 2009, s. 147). Jednakże uzyskanie wpływu na politykę państwa przez samych Egipcjan nie oznaczało końca problemów. Wręcz przeciwnie, jak się miało okazać, działania podejmowane przez kolejnych rządzących doprowadziły do powstania głębokiego podziału w społeczeństwie egipskim. Członkowie państwowych elit posiadali koneksje oraz gromadzili kapitał, które zapewniały im zarówno polityczną, jak i finansową przewagę nad resztą obywateli. W tym gronie chlubny wyjątek stanowił prezydent Gamal Naser, na którego koncie po śmierci zostało zaledwie 610 funtów egipskich (Stępniewska-Holzer, Holzer, 2006, s. 116).

W ramach wspomnianych elit państwowych Egiptu pozycję dominującą zajęli wojskowi, którzy dzięki swojemu udziałowi w procesie obalenia monarchii mogli liczyé na wdzięczność i wyjątkową przychylność ze strony większości obywateli. Taka sytuacja miała miejsce już za prezydentury Gamala Nasera, który opowiadał się za udziałem armii w rządach, by ograniczyć możliwość przejęcia władzy przez członków Bractwa Muzułmańskiego. Zresztą była to jedna z kwestii, które doprowadzily do politycznej konfrontacji pomiędzy Naserem a Nagibem - zwolennikiem demokratyzacji życia politycznego w Egipcie. Ostatecznie z próby sił zwycięsko wyszedł Naser, który w 1954 roku zastąpił Nagiba na stanowisku prezydenta Egiptu.

Jak słusznie zauważa Gilbert Achcar, od tego momentu armia stanowiła podstawę funkcjonowania władzy w Egipcie (Achcar, 2013, s. 149). Wojskowi zyskali nie tylko bezpośredni wpływ na politykę państwa, ale także na jego rozwój gospodarczy. Egipska armia zyskała na znaczeniu w okresie prezydentury Gamala Nasera, a jej pozycja została ugruntowana za rządów kolejnych prezydentów - Anwara Sadata oraz Hosni Mubaraka. W rezultacie powstał system polityczny, w którym gwarancję pozostania u władzy stanowily albo dobre relacje $\mathrm{z}$ armia, albo dopuszczenie wojskowych do bezpośredniego udziału w organach władzy wykonawczej. Co więcej, za rządów Nasera, nowe elity polityczne wprowadzały do systemu elementy socjalizmu i prowadziły politykę zbliżenia ze Związkiem Radzieckim (Ginat, 1997, s. 195). W sferze gospodarczej reformy nie pomogły jednak rozwiązać najpilniejszych problemów i tym samym władze Egiptu były zmuszone do zmiany prowadzonej polityki w połowie lat 70 . 
Prezydent Anwar Sadat doprowadził do otwarcia egipskiego rynku dla inwestycji zagranicznych. Pakiet wprowadzonych reform określono mianem infitah - 'the Opening' (El-Naggar, 2009, s. 34). Sytuacja gospodarcza zaczęła się jednak pogarszać po zabójstwie Sadata w październiku 1981 roku. W latach osiemdziesiątych Mubarak zablokował szereg reform gospodarczych, zainicjowanych przez Sadata, i przywrócił centralne planowanie gospodarcze, charakterystyczne dla rządów Nasera (Soliman, 2012, s. 45). W rezultacie, już w pierwszej połowie lat osiemdziesiątych XX wieku, Egipt zmagał się ze złożonymi problemami ekonomicznymi, w tym z niestabilnym wzrostem gospodarczym. Wysoki poziom bezrobocia wraz z gwałtownym spadkiem wpływów do budżetu wiązał się z koniecznością ograniczania wydatków, zwłaszcza w sferze socjalnej, oraz zmniejszanie państwowych subsydiów. Jak słusznie zauważył Michał Lipa, „był to cios zadany niepisanej umowie społecznej, polegającej na tym, że Egipcjanie - w zamian za gwarancję względnie dobrych warunków życia - na jakie nie było ich stać - nie kontestowali autorytarnych stosunków politycznych. W momencie, gdy owa umowa została złamana, zaczął znikać główny czynnik legitymizujący niedemokratyczną władzę Mubaraka oraz jego reżimu, który był zmuszony do częstszego uciekania się do przemocy" (Lipa, 2014, s. 9). Podobnego zdania jest Bruce K. Rutherford, który twierdzi, iż od lat sześćdziesiątych władze Egiptu gwarantowały swym obywatelom szereg subsydiów, a także zatrudnienie, które stanowiły ważny element legitymizacji kolejnych rządów. Jednakże z czasem subsydia stawały się coraz droższe, gospodarka nie generowała wystarczająco wysokich przychodów, a populacja Egiptu rosła o wiele szybciej aniżeli zakładano (Rutherford, 2008, s. 1).

Na początku XXI wieku bardzo ważną rolę w egipskiej polityce odegrał ruch Kefaya - 'Enough'. Ruch Kefaya oraz inne, współpracujące z nim grupy były określane mianem Harakat al-Tag'eer - 'Movements for Change'. Po raz pierwszy od wielu lat Egipcjanie wzięli udział w antyrządowych protestach. Choć nie miały tak masowego charakteru jak te $\mathrm{z} 2011$ roku, przyciagały uwagę zarówno Egipcjan, jak i wielu zagranicznych komentatorów. Członkowie ruchu Kefaya rozpoczęli uliczne protesty w grudniu 2004 roku, gdy prezydent Hosni Mubarak zasugerowal, iż chciałby pozostać na stanowisku na piątą kadencję. Ponadto, jednocześnie z kręgów rządowych coraz częściej napływały informacje o tym, że Mubarak planuje rodzinną sukcesję władzy prezydenckiej i stopniowo przygotowywał do tej roli swego młodszego syna, Dżamala. Wkrótce protesty Kefayi uzyskały poparcie ze strony wpływowych grup zawodowych, na przykład, pracowników naukowych, pisarzy, dziennikarzy, artystów, a także studentów. Wszyscy oni opowiadali się za zmianami politycznymi w Egipcie pod hasłem Egipski Ruch dla Zmian (al Sayyid, 2009, s. 45). Członkowie ruchu Kefaya stawiali dwa podstawowe żądania. Domagali się rezygnacji Hosni Mubaraka z kolejnego startu w wyborach prezydenckich oraz gwarancji, że w wyborach nie będzie brał udziału także jego syn Dżamal (Tadros, 2014, s. 149).

W tym kontekście należy jednak wyraźnie zaznaczyć, iż zdaniem niektórych autorów pomysł przekazania stanowiska Dżamalowi Mubarakowi nie był pomysłem ani samego prezydenta, ani też jego syna, lecz najbliższych doradców politycznych, którzy w ten sposób chcieli zabezpieczyć swoją przyszłość po ewentualnym odejściu w stan spoczynku lub też śmierci Hosni Mubaraka (Amin, 2011, s. 149). Stronnicy prezydenta obawiali się najpewniej, iż brak konsensusu w sprawie sukcesji oraz brak wyraźnego wskazania następcy przez samego Mubaraka mogłyby doprowadzić do niekontrolowanej rywaliza- 
cji wewnętrznej w ramach rządzącej Partii Narodowo-Demokratycznej, NDP (arab. al-Hizb al-Watani al-Dimuqrati).

Kefaya straciła na znaczeniu po wyborach prezydenckich w 2005 roku. Jej słabymi stronami okazały się wewnętrzne podziały oraz brak doświadczenia politycznego większości działaczy (El-Mahdi, 2009, s. 88). Hosni Mubarak wyciagnął wnioski z konfrontacji z Kefayą i wzmocnił aparat represji oraz kontrolę mediów. Równolegle rosły wpływy polityczne i społeczne Bractwa Muzułmańskiego, które odniosło sukces podczas wyborów w 2005 roku i jednocześnie podejmowało współpracę z liderami ruchu Kefaya (Zahid, 2012, s. 125).

Bractwo stanowiło atrakcyjną alternatywę polityczną dla osób spoza tzw. establishmentu, a zwłaszcza dla przeciwników sekularyzmu, wszystkich zainteresowanych ograniczeniem wpływów armii w państwie, a także bezrobotnych i młodych Egipcjan. Egipskie władze przez wiele lat próbowały wyeliminować lub przynajmniej poważnie ograniczyć wpływy Bractwa, ale, jak się miało okazać, były to działania w dużej mierze nieskuteczne. Warto jednak nadmienić, iż podczas pierwszej dekady swych rządów Hosni Mubarak podejmował próby wciagnięcia Bractwa Muzułmańskiego w szerszą koalicję polityczną, której głównym celem miało być wyeliminowanie ugrupowań fundamentalistycznych na czele z Tandheem al-Jihad oraz Gamaah al-Islamiyah (Bokhari, Senzai, 2013, s. 51). Jak zauważył Andrzej Purat, „w czasie rządów Hosni Mubaraka Bracia Muzułmanie prowadzili działalność dobroczynną i oświatową, na którą mieli zgodę władz. Jednocześnie podejmowali próby, aby przy swoim stowarzyszeniu zarejestrować partię polityczną. Jednak władze odmawiały, bowiem egipskie prawo o partiach nie pozwalało na zalegalizowanie takiej organizacji, która odwoływała się do religii" (Purat, 2014, s. 223).

Dla Hosni Mubaraka pierwszym sygnałem odradzania się siły Bractwa Muzułmańskiego w Egipcie były wyniki wyborów parlamentarnych z listopada 2005 roku. Pomimo rozmaitych restrykcji oraz ograniczeń nałożonych na kandydatów Bractwa, na przykład, liczbę możliwych do zgłoszenia kandydatów ograniczono zaledwie do 150 osób, ruch zdołał zapewnić sobie aż 88 mandatów - w przybliżeniu około $20 \%$ miejsc w parlamencie. Równocześnie członkowie tak zwanych sekularnych ugrupowań politycznych zdobyli zaledwie 14 mandatów, czyli tylko około 3\% ogólnej ich liczby (Naguib, 2009, s. $155-156)$.

Walid Kazzih utrzymuje, iż do stycznia 2011 roku egipską opozycję można było podzielić na dwie grupy. Pierwszą z nich stanowiły siły polityczne, które albo odrzucały system polityczny obowiązujący w czasach prezydentury Hosni Mubaraka, albo też odmawiały stosowania się do wyznaczonych przezeń zasad. Do tej grupy Kazzih zaliczył, między innymi, Partia Frontu Narodowego, ruch Kefaya oraz Mohameda el-Baradei. Z kolei w drugiej grupie znalazły się ugrupowania, które starały się wykorzystać słabości systemu politycznego i celowo dążyły do jego destabilizacji. Wśród nich wymienione zostały Bractwo Muzulmańskie, Partia Wafd oraz Partia Tegammu (Kazzih, 2013, s. 30). Opozycja była zatem podzielona, poszczególne ugrupowania miały różne cele, toteż trudno było sobie wyobrazić jakąkolwiek zorganizowaną siłę, mogącą doprowadzić do odsunięcia Mubaraka oraz jego stronników od władzy po blisko trzydziestu latach rządów. Tym bardziej, że służby bezpieczeństwa wewnętrznego były wyjątkowo dobrze zorganizowane, a po stronie prezydenta stała także armia, ciesząca się w Egipcie wielkim 
szacunkiem i szerokimi wpływami polityczno-ekonomicznymi. Jednak, jak się miało wkrótce okazać, to nie zorganizowana siła polityczna miała stanowić największe zagrożenie dla reżimu, lecz masa jednostek niezadowolonych z sytuacji w państwie. Trzon tej spontanicznie powstałej grupy stanowili młodzi ludzie, którzy postanowili postąpić tak samo jak ich rówieśnicy w Tunezji i doprowadzić do wymiany elity rządzącej.

\section{Przebieg rewolucji w 2011 roku}

25 stycznia 2011 roku na ulice Kairu, Aleksandrii oraz wielu innych egipskich miast wyszły tysiące ludzi. Spontanicznie dzień ten określono Dniem Gniewu. Na kairskim placu Tahrir pojawiły się tłumy demonstrantów, którzy powtarzali znamienny slogan, zawierający esencję podstawowych żądań i oczekiwań społecznych: 'aish, hurriyya, karama insaniyya' - chleb, wolność, godność ludzka (Clarke, 2013, s. 197). Nadspodziewanie brutalne działania ze strony policji oraz aparatu bezpieczeństwa przyczyniły się jedynie do umocnienia oporu oraz dalszego umasowienia protestów. Zdaniem Bahgata Korany’ego oraz Rababa El-Mahdiego, brutalność policji jedynie zwiększała liczbę protestujących do takich rozmiarów, że nie było już możliwości zapanowania nad tłumem. W dodatku dowództwo sił policyjnych było silnie podzielone w sprawie działań, które należało podejmować (Korany, E1-Mahdi, 2012, s. 11).

Spontaniczny ruch protestu zyskiwał na sile oraz zasięgu głównie dzięki powszechnemu dostępowi do mediów społecznościowych. Młodzi Egipcjanie wzięli przykład z Tunezyjczyków i udostępniali rozmaite informacje dotyczące przebiegu protestów, a także mobilizowali się wzajemnie za pośrednictwem takich serwisów jak YouTube czy też Facebook. Najbardziej znanym internetowym aktywistą stał się Wael Ghonim, który założył oraz rozpropagował stronę na Facebooku, poświęconą Khaledowi Saeedowi (Ghonim, 2012, s. 58). Saeed był egipskim studentem, który został brutalnie zamordowany przez dwóch oficerów policji wkrótce po aresztowaniu w jednej z kafejek internetowych w Aleksandrii w czerwcu 2010 roku. Sprawa nabrała rozgłosu po tym jak członkowie jego rodziny opublikowali w sieci zdjęcia okaleczonych zwłok. To wydarzenie zainspirowało Waela Ghonima. Założona przez niego strona nosiła wymowny tytuł 'We are all Khaled Saeed' - Kullena Khaled Said. Do grudnia 2014 roku 'polubiło ją' blisko 336 tysięcy zarejestrowanych użytkowników.

Kairski plac Tahrir ponownie stał się symbolem protestów. Ich przebieg obserwowali z uwagą zagraniczni dziennikarze. Przy okazji warto nadmienić, iż plac Tahrir zyskał swą obecną nazwę jeszcze w okresie rządów Dżamala Abdela Nasera, który w ten sposób chciał upamiętnić odrzucenie monarchii w 1952 roku. Obecnie miejsce to budzi zatem i pozytywne skojarzenia, i te negatywne, związane z represyjnym reżimem Hosni Mubaraka (Schwedler, King, 2014, s. 169-170).

Ponad dwutygodniowe protesty zaowocowały sukcesem demonstrantów. 11 lutego prezydent Mubarak zrezygnował ze stanowiska, a władzę w państwie przejęła Rada Najwyższa Sił Zbrojnych, na czele z marszałkiem polnym Husseinem Tantawim. Jednocześnie rozpoczęy się przygotowania do przeprowadzenia reform konstytucyjnych. Kilka miesięcy później Hosni Mubarak, jego syn Dżamal oraz kilku najbliższych współpracowników stanęło przed sądem. Ze względów bezpieczeństwa oraz w związku z poważ- 
nymi problemami zdrowotnymi, Hosni Mubarak był przez długi czas przetrzymywany w szpitalu w Sharm el-Sheikh na Synaju.

\section{Przyczyny polityczne}

Michał Lipa twierdzi, iż egipski system polityczny można było określić jako „semiautorytarny, gdyż - obok zdecydowanej przewagi egzekutywy - mieliśmy do czynienia z elementami demokracji, takimi jak instytucja wyborów parlamentarnych czy - od 2005 roku - także prezydenckich. Jednak istnienie zarówno skutecznego aparatu represji, jak również restrykcyjnego prawa, instytucji stanu wyjątkowego, podsystemu sądownictwa specjalnego oraz organizacji i instytucji wspierających reżim nie pozostawiało wątpliwości co do prawdziwej natury systemu" (Lipa, 2013, s. 101).

Do przyczyn politycznych wybuchu niezadowolenia społecznego w styczniu 2011 roku zaliczyć można wynik wyborów parlamentarnych z jesieni 2010 roku. Zwycięstwo odniosła National Democratic Party, uzyskując ponad $90 \%$ mandatów. Rozmiary wyborczego sukcesu partii rządzącej budziły jednak wątpliwości nie tylko opozycji, ale także niezależnych obserwatorów. Wystarczy wspomnieć, że Bractwo Muzułmańskie zdołało zdobyć zaledwie jeden mandat. Wspierany przezeń kandydat wziął udział w wyborach jako niezależny (Sharp, 2011, s. 19).

Zdaniem wielu analityków, do wybuchu gwałtownych protestów społecznych w Egipcie doprowadził także sukces Tunezyjczyków, którzy zdołali odsunąć od władzy wpływowego prezydenta - Ben Alego. Jego pozycja przez wiele lat wydawała się niepodważalna, zwłaszcza ze względu na osobistą kontrolę nad kluczowymi sektorami gospodarki oraz aparatem bezpieczeństwa. Tymczasem spontaniczne protesty, organizowane przy wykorzystaniu nowoczesnych mediów społecznościowych, a także będąca ich konsekwencją utrata kontroli nad armią, zmusiły Ben Alego do ustąpienia oraz wyjazdu z Tunezji (Achcar, 2013, s. 145-147). Był to sygnał ostrzegawczy dla innych autokratycznych przywódców w regionie Afryki Północnej i Bliskiego Wschodu, w tym także dla prezydenta Egiptu. Jednocześnie tunezyjski kazus stanowił przykład dla społeczeństw takich jak egipskie - zmęczonych arogancją władzy, ograniczaniem podstawowych praw i wolności, a także represjami na tle politycznym (Sharp, 2012, s. 48). Nieco inny punkt widzenia reprezentuje jednak Samuel Tadros, którego zdaniem z początku Egipcjanie wcale nie śledzili z uwagą wydarzeń w Tunezji. Magreb, choć też arabski, nie przyciąga uwagi Egipcjan i nie cieszy się ich zainteresowaniem tak jak arabskie państwa Lewantu. Dopiero ucieczka Ben Alego z Tunezji 13 stycznia 2011 roku doprowadziła do zmiany. Niespodziewany sukces tunezyjskiej opozycji stał się źródłem inspiracji dla mieszkańców Egiptu. To właśnie wtedy Wael Ghonim wezwał do organizacji masowego protestu przeciwko Hosni Mubarakowi - Dnia Gniewu - 25 stycznia (Tadros, 2014, s. 334).

Inną przyczynę stanowił brak pluralizmu politycznego, a zwłaszcza wyeliminowanie z rywalizacji o władzę wpływowych organizacji o charakterze wyznaniowym, z Bractwem Muzułmańskim na czele. W opinii Alego Abi Issy, „elita wykształcona zgodnie z zachodnią myślą orientalistyczną stanowiła główne środowisko oraz zaplecze dla niedemokratycznych ustrojów panujących w krajach muzułmańskich w okresie postkolo- 
nialnym. Dostarczała im wsparcia w walce o utrzymywanie rozdziału władzy od religii, wykluczania panislamistów bez względu na wyznawane przez nich doktryny, a także w ogóle traktowanie religii jako źródła cywilizacyjnego zacofania trapiącego świat muzułmański" (Issa, 2011, s. 14).

Wśród przyczyn odsunięcia Hosni Mubaraka od władzy wymieniana jest także wewnętrzna rywalizacja wśród członków elity rządzącej, zwłaszcza w ramach Partii Narodowo-Demokratycznej. Już kilka miesięcy po zwycięstwie rewolucji ze stycznia 2011 roku, NDP została oficjalnie rozwiązana, a jej majątek w całości przekazany skarbowi państwa. Nie zmienia to jednak faktu, że jej członkowie zachowali duże, prywatne majątki oraz szerokie wpływy gospodarcze. Ponadto, w kregach dowódczych armii zmiany były niewielkie. Protestujący starali się nie prowokować wojskowych, ponieważ armia nie wystąpiła przeciwko nim w styczniu. Można nawet zauważyć, iż armia kolejny raz skorzystała z okazji, by stanąć na straży porządku publicznego i tym samym przejąć rzeczywistą kontrolę nad życiem politycznym w państwie. Za śmierć demonstrantów oraz próby siłowego zdławienia protestów oskarżano personalnie Hosni Mubaraka oraz kontrolowany przezeń aparat bezpieczeństwa. Dzięki temu armia mogła stanąć po zwycięskiej stronie i zabezpieczyć własne interesy, na przykład, utrzymać kontrolę nad wieloma hotelami w kurortach, a także wielkie majątki poszczególnych wyższych oficerów.

Trudno jednak nie zgodzić się z opinią Joshua Stacher, iż ,w trakcie osiemnastu dni Egipt przeszedł przez proces przyspieszonej transformacji ustrojowej, od autorytaryzmu Mubaraka do systemu ustanowionego przez zwycięskie siły rewolucyjne. Jednakże rewolucja pozostała niedokończona, ponieważ zmianie nie uległy podziały społeczne. W niektórych przypadkach sami liderzy sił rewolucyjnych nieświadomie wzięli udział w powieleniu hierarchii klasowej" (Stacher, 2012, s. 159). Ponadto, lata dominacji partii rządzącej NDP ograniczyły dostęp do władzy politykom opozycji i z tego powodu zdecydowana większość z nich nie dysponowała żadnym doświadczeniem. Na Zachodzie wiązano duże nadzieje z osobą Muhammada el-Baradei, byłego dyrektora generalnego Międzynarodowej Agencji Energii Atomowej (MAEA) i laureata Pokojowej Nagrody Nobla. Baradei mógł jednak liczyć jedynie na poparcie ze strony liberalnej i postępowej części społeczeństwa. Podobno miał zostać premierem Egiptu po zamachu wojskowym z lipca 2013 roku, ale nie objął stanowiska ze względu na sprzeciw ze strony salafickiej partii al-Noor (Sen, 2013). W zamian został wiceprezydentem, choć, jak się miało okazać, jedynie na miesiąc.

Kontrrewolucja z lipca 2013 roku, odsunięcie od władzy Bractwa Muzułmańskiego oraz późniejszy wybór na prezydenta Egiptu generała Sisiego wydają się potwierdzać słuszność obserwacji Joshuy Stachera. Po upływie ponad czterech lat od rewolucji ze stycznia 2011 roku można nawet stwierdzić, iż w Egipcie nie doszło do wymiany elity rządzącej, lecz jedynie do rekonfiguracji w ramach elity związanej z Partią Narodowo-Demokratyczną oraz armią. Obecny prezydent Egiptu, Abdel Fattah as-Sisi, w ostatnim okresie rządów Hosni Mubaraka obją stanowisko szefa egipskiego wywiadu wojskowego i zajmował je aż do sierpnia 2012 roku, gdy został ministrem obrony oraz głównodowodzącym egipskich sił zbrojnych. W rezultacie jego prezydentura może, w perspektywie długookresowej, zaowocować jeszcze większym umocnieniem wpływów armii zarówno w polityce, jak i gospodarce. 


\section{Przyczyny gospodarcze i spoleczne}

Reformy gospodarcze z okresu prezydentury Sadata nie przyniosły zamierzonych skutków. Problemy państwa uległy pogłębieniu za rządów Mubaraka. W tym kontekście należy zwrócić uwagę przede wszystkim na wielki przerost biurokracji. Pod koniec 2010 roku w administracji państwowej pracowało już ponad 5,5 $\mathrm{mln}$ Egipcjan. Dla porównania - państwowe przedsiębiorstwa zatrudniały zaledwie 600 tys. osób (Kandil, 2012, s. 203). Równolegle nie powstawały nowe miejsca pracy w sektorze prywatnym, co jedynie potęgowało problem bezrobocia, zwłaszcza wśród absolwentów. Zresztą ich sytuacja była trudna już od 1995 roku, gdy Międzynarodowy Fundusz Walutowy - IMF wymusił na egipskich władzach rezygnację z gwarancji zatrudniania absolwentów wyższych uczelni. Był to element programu naprawczego. Ponadto, w tym samym okresie egipski rząd zredukował poziom subsydiów o ponad $75 \%$ w porównaniu z ich poziomem w latach osiemdziesiątych (Kandil, 2012, s. 205). Według Nadii Ramsis Farah, w przeciwieństwie do innych państw wchodzących na drogę industrializacji, egipski eksperyment zakończył się niepowodzeniem i doprowadził do ekonomicznej dominacji ze strony stosunkowo nielicznej części społeczeństwa (Farah, 2009, s. 52).

W kontekście przyczyn tak zwanej arabskiej wiosny, Gilbert Achcar zwrócił uwagę na rosnący problem bezrobocia oraz, co z tym ściśle związane, powiększające się grono wykluczonych we współczesnych społeczeństwach arabskich. Jego zdaniem, także w Egipcie, wyróżnić można trzy główne grupy, dotknięte problemem braku stałej pracy:

- młodziez;

— kobiety;

— absolwenci wyższych uczelni (Achcar, 2013, s. 22-37).

Zdaniem Dżalala Amina, egipskie władze próbowały przeciwdziałać zjawisku bezrobocia wśród młodych, „udając, że starają się rozwiązać problem poprzez utworzenie specjalnego ministerstwa, Ministerstwa ds. Młodzieży, lub przedstawiając statystyki potwierdzające spadek bezrobocia, które w rzeczywistości rosło z każdym dniem. Musiały też liczyć zatrudnionych i bezrobotnych w określony sposób, który pozwalał wliczać bezrobotnych młodych ludzi w szeregi oficjalnie zatrudnionych" (Amin, 2013, s. 20). Tym samym nie sposób nie zgodzić się z opinią, iż państwo egipskie nie podejmowało zdecydowanych działań celem tworzenia nowych miejsc pracy i w pewnym sensie zrezygnowało $\mathrm{z}$ aktywnego wspierania rozwoju gospodarczego (Farah, 2009, s. 52).

Możliwości rozwoju gospodarczego Egiptu zostały również ograniczone ze względu na dekoninukturę na rynku światowym, będącą konsekwencją kryzysu finansowego z 2008 roku. Zdaniem Jerzego Zdanowskiego, „w 2009 roku oddziaływanie kryzysu pogłębiło się nie tylko ze względu na bariery w inwestowaniu i kredytowaniu, ale głównie z uwagi na spadek cen ropy, ograniczenie ruchu turystycznego i niższe kwoty przesyłane do kraju przez obywateli pracujaccych za granicą" (Zdanowski, 2011, s. 73).

W kontekście przyczyn społecznych rewolucji egipskiej, należy zwrócić uwagę na szerszy, regionalny kontekst kulturowy, charakterystyczny zarówno dla Egiptu, jak i dla innych państw bliskowschodnich. I to nie tylko arabskich. Jak słusznie zauważył Jerzy Zdanowski, ,rzeczywistość Bliskiego Wschodu jest wymownym przykładem oddziaływania kultury na stosunki społeczne. Relacje między pracodawcą a pracownikiem, 
właścicielem ziemskim a dzierżawcą ziemi, dyrektorem szkoły a rodzicami, przywódcą partii a jej członkami są silnie spersonalizowane" (Zdanowski, 2013, s. 38). Tym samym wielu młodych Egipcjan, których rodziny pozbawione były szerszych koneksji, skazanych było na życie na marginesie. Warto dodać, że wspomniany problem nie stanowił jedynie konsekwencji stylu sprawowania władzy przez Mubaraka i jego współpracowników, choć niewątpliwie członkowie dawnego reżimu przyczynili się do umocnienia i rozwoju zjawiska klientelizmu we współczesnym Egipcie. Niemniej, nic nie wskazuje na to, by sytuacja ulegała poprawie w okresie postrewolucyjnym. Nadal można wskazać duże grupy wykluczonych, którzy nie mają szans na karierę $\mathrm{w}$ administracji państwowej czy armii. Po 2013 roku jedną z takich grup stanowią członkowie oraz sympatycy Bractwa Muzułmańskiego.

\section{Kontrrewolucja w 2013 roku: przyczyny, przebieg, konsekwencje}

Jeszcze w 2011 roku niektórzy komentatorzy dowodzili, iż ruch Braci Muzułmanów w Egipcie dojrzał do tego, by rywalizować o władzę przy wykorzystaniu legalnych środków, a także sprawować ją z korzyścią dla całego społeczeństwa, choć równocześnie jego przywódcy byli podzieleni jak nigdy przedtem. Jedną z nich była Carrie Rosefsky Wickham, która na łamach „Foreign Affairs” przekonywała, iż przez ponad 30 lat przywódcy i członkowie Bractwa Muzułmańskiego nabrali odpowiedniego doświadczenia politycznego i byli gotowi brać aktywny, odpowiedzialny udział w samodzielnym rządzeniu lub współrządzeniu Egiptem. Ponadto, Wickham przekonywała, że żaden proces przemian demokratycznych bez włączenia weń Bractwa nie będzie mógł zakończyć się powodzeniem (Wickham, 2014). Ta i podobne opinie uzyskały potwierdzenie podczas wyborów parlamentarnych na przełomie 2011 i 2012 roku. Powiązana z Bractwem Partia Wolności i Sprawiedliwości odniosła w nich wielki sukces, uzyskując ponad 37,5\% głosów i wyprzedzając salaficką partię islamistyczną, Al Nour, z 20\% oraz liberałów - 15\% (Sedky, 2013, s. V-VI). Jeśli dodać do tego sukces Mohammada Mursiego w wyborach prezydenckich, wygrana Bractwa Muzułmańskiego wydawała się być całkowita. Jeszcze kilka lat wcześniej jakikolwiek udział członków Bractwa we władzach państwowych wydawał się zupełnie nierealny. Tymczasem w 2012 roku Bractwo zdobyło wpływ nie tylko na władzę ustawodawczą, ale także na wykonawczą.

Głównym zadaniem nowowybranego parlamentu było powołanie stu członków Egipskiego Zgromadzenia Ustawodawczego, odpowiedzialnego za opracowanie tekstu nowej konstytucji. Po jego powołaniu, rozpoczęła się prawna batalia z udziałem Najwyższego Sądu Konstytucyjnego, który dążył do zablokowania prac nad dokumentem ze względu na zbyt duże wpływy Bractwa Muzułmańskiego oraz salafitów. 14 czerwca sąd uznał wybory za niekonstytucyjne i nieważne. Co ciekawe, w innym orzeczeniu trybunał unieważnił też dekret zakazujący startu w wyborach członkom rozwiązanej partii Hosni Mubaraka (Egypt Supreme, 2012). W rezultacie, pod naciskiem trybunału oraz opinii publicznej, skład zgromadzenia został poszerzony o przedstawicieli rozmaitych innych partii politycznych oraz instytucji. Problemem stał się jednak bojkot posiedzeń zgromadzenia ze strony wielu członków opozycji. Pomimo tego, Egipskie Zgromadzenie Ustawodawcze zatwierdziło treść nowej konstytucji 29 listopada 2012 roku. 
Obawy części egipskiego społeczeństwa budzily deklaracje niektórych członków Bractwa, a także członków partii al-Nour, dotyczące większej ingerencji państwa w kwestie światopoglądowe. Grupą wyznaniową, która najmocniej odczuła zmianę po 2011 roku byli egipscy koptowie. Wkrótce reprezentanci Bractwa mieli zostać zmuszeni nie tylko do rezygnacji z zajmowanych stanowisk, ale także do całkowitego wycofania się z legalnej działalności politycznej. W opinii Bruno Drwęskiego, „w Egipcie, gdzie wcześniej naród wykazał się energią rewolucyjną, legalny rząd islamistyczny nie potrafił skutecznie zmobilizować społeczeństwa w swej obronie" (Drwęski, 2014, s. 9). Słabość i brak politycznego doświadczenia polityków Bractwa Muzułmańskiego zachęciły armię do interwencji pod hasłem obrony porządku publicznego.

Przyjmuje się, iż egipska kontrrewolucja rozpoczęła się 30 czerwca 2013 roku. W tym dniu aresztowany został prezydent Morsi. Oskarżono go o zachęcanie do użycia przemocy, a także, co wywołało największe kontrowersje, o szpiegostwo i konspiracyjną współpracę z Hezbollahem i Hamasem celem zdestabilizowania sytuacji w Egipcie (Abdallah, 2013). Przez kilka poprzedzających tygodni przeciwnicy rządów Bractwa oraz prezydenta wzywali egipskie społeczeństwo do otwartego wystapienia przeciwko władzom państwa. W opinii wielu analityków członkowie Bractwa, kontrolując władzę w Egipcie, nie wykorzystali swojej szansy. W krótkim czasie narazili się wielu funkcjonariuszom służb bezpieczeństwa, policji, armii oraz sędziom, którzy od lat mieli decydujący wpływ na egipskie życie polityczne. Przeciwko sobie mieli także wielu polityków związanych z reżimem Mubaraka, a także, co okazało się być decydujące, znaczną część egipskiego społeczeństwa. Bractwo nie potrafiło także odpowiednio szybko wykryć i zapobiec próbie odsunięcia od władzy w czerwcu 2013 roku. Główną przyczyną takiego stanu rzeczy był brak doświadczenia politycznego oraz pełnej kontroli nad policją oraz służbami bezpieczeństwa (Al-Banna, 2014, s. 951). Wkrótce, po usunięciu Morsiego z urzędu, na ulice wyszły tysiące jego zwolenników. Symbolicznym miejscem protestów sympatyków Bractwa stał się kairski plac Raba'a. Tym samym egipskie społeczeństwo zostało poddane nowemu, symbolicznemu podziałowi na tych, którzy występowali przeciwko rządom Bractwa i zbierali się lub wspierali protestujących na placu Tahrir oraz na zwolenników kontynuacji rządów Bractwa spod znaku placu Raba'a. Wkrótce miało się okazać, że konfrontacja między tymi dwoma obozami będzie wyjątkowo krwawa, a liczba ofiar śmiertelnych znacznie przekroczy liczbę ofiar z okresu rewolucji z początku 2011 roku.

Zwolennicy obalonego prezydenta Morsiego niezmiennie określali zmianę polityczną z lipca 2013 roku jako zamach stanu, natomiast jego przeciwnicy stosowali termin egipskiej rewolucji z 2013 roku. Do momentu wyboru i zaprzysiężenia nowego prezydenta w czerwcu 2014 roku, obowiązki głowy państwa przejął przewodniczący egipskiego Trybunału Konstytucyjnego Adly Mansour. Niemniej żaden z obserwatorów nie miał wątpliwości, iż pierwszoplanową postacią lipcowego przewrotu był marszałek polny Abdel Fattah el-Sisi, który od sierpnia 2012 aż do marca 2014 roku pełnił funkcje ministra obrony i głównodowodzącego egipskich sił zbrojnych, a od lipca 2013 do marca 2014 roku także wicepremiera Egiptu. Co niezwykle istotne, zarówno przed, jak i po przewrocie, Sisi mógł liczyć na znaczące wsparcie ze strony Arabii Saudyjskiej oraz kilku innych zamożnych i wpływowych państw arabskich z rejonu Zatoki Perskiej (Cambanis, 2015, s. 248). 


\section{Rządy prezydenta Sisiego: szansa na stabilizację?}

W maju 2014 roku kairski sąd zabronił członkom rozwiązanej w 2011 roku the National Democratic Party startu w wyborach. Wkrótce potem odbyły się wybory prezydenckie, w których zwyciężył Abdel Fattah el-Sisi. I chociaż bardzo wyraźnie pokonał Hamdeen Sabahi, uzyskując aż 96,91\% głosów, to komentatorzy zwrócili uwagę na bardzo niską frekwencję, która wyniosła zaledwie 47,5\% (El-Sisi, 2014). Nie pomogło nawet ogłoszenie dnia wolnego od pracy oraz przedłużenie wyborów o jeden dzień. Z pewnością duży wpływ na taki stan rzeczy miał fakt, iż zwolennicy Bractwa Muzułmańskiego zbojkotowali wybory. Można uznać, że tym samym zamknięty został kolejny rozdział w postrewolucyjnej historii Egiptu. Prezydent Sisi obiecał Egipcjanom ustabilizowanie sytuacji politycznej, reformy gospodarcze, a także, być może przede wszystkim, ostateczne wykluczenie Bractwa Muzułmańskiego z polityki.

O ile rzeczywiście udało mu się wyeliminować Bractwo z legalnej walki o władzę oraz poważnie ograniczyć jego wpływy, o tyle ani nie poprawił się stan bezpieczeństwa, ani sytuacja gospodarcza. Analitycy „The Economist” prognozują dla Egiptu w 2015 roku wzrost gospodarczy na poziomie 3,3\% (The World, 2014, s. 100). W dobie walki ze skutkami światowego kryzysu można uznać powyższą prognozę za dobrą jednak jednocześnie należy podkreślić, iż w przypadku Egiptu wartość wzrostu jest zdecydowanie zbyt niska, by gwarantować odczuwalną poprawę sytuacji finansowej większości obywateli. Z kolei próba zmarginalizowania wpływów Bractwa Muzułmańskiego może, podobnie jak to miało miejsce w przeszłości, doprowadzić do wyraźnej radykalizacji jego członków. Jest bardzo prawdopodobne, że podejmą oni działalność o charakterze antysystemowym, z wykorzystaniem wszelkich dostępnych środków, z użyciem przemocy i terrorem włącznie. Wydarzenia z 2013 roku doprowadziły do pogłębienia podziałów pomiędzy Egipcjanami, także przedstawicielami młodzieży, którzy wspólnie doprowadzili do ustąpienia Hosni Mubaraka w lutym 2011 roku. Problem jest jednak znacznie poważniejszy i bardziej złożony. Jak słusznie zauważył Artur Wejkszner, ,islamizm czy też dżihadyzm z jednej strony i prodemokratyczne ruchy młodzieży islamskiej w państwach Afryki Północnej stoją wobec siebie w opozycji. Dzieje się tak z uwagi na aprioryczne odrzucenie przez dżihadystów zachodniej kultury i tradycji politycznej, do której powyższa młodzież jednoznacznie się odwołuje" (Wejkszner, 2014, s. 198).

\section{Wnioski}

Na zmianę elit rządzących Egiptem, w tym personalnie - odsunięcie od władzy prezydenta Hosniego Mubaraka, złożył się szereg przyczyn o charakterze politycznym, gospodarczym oraz społecznym. Z kolei w przypadku kontrrewolucji z lipca 2013 roku, decydujące znaczenie miały czynniki o charakterze politycznym oraz światopoglądowym.

Wśród przyczyn politycznych rewolucji z 2011 roku bezsprzecznie najważniejszymi były brak pluralizmu oraz represjonowanie członków ugrupowań opozycyjnych. Polityka wykluczenia członków Bractwa Muzułmańskiego czy też opozycji skupionej wokół ruchu Kefaya skutkowała stopniową alienacją elity rządzącej. Do odsunięcia od władzy prezydenta Hosni Mubaraka przyczyniła się także rywalizacja wewnętrzna w ramach 
rządzącej Partii Narodowo-Demokratycznej (NDP) oraz w kręgach dowódczych egipskiej armii. Symbolem represji oraz bezwzględności reżimu stała się śmierć Khalled Saeed. Wael Ghonim przyczynił się do nagłośnienia tej sprawy za pośrednictwem mediów społecznościowych i tym samym nadał procesowi rewolucyjnemu nowej dynamiki, niespotykanej wcześniej w Egipcie. W 2005 roku przywódcy ruchu Kefaya nie mieli jeszcze do swojej dyspozycji tak skutecznych środków przekazu. Wydarzenia z przełomu stycznia i lutego 2011 roku zjednoczyły większość społeczeństwa, a także opozycyjnych polityków, bez względu na różnice światopoglądowe. Wspólnym celem było odsunięcie od władzy Hosni Mubaraka oraz członków rządzącej partii NDP. Gdy cel ten udało się już osiagnąć, pojawił się problem ze stworzeniem wspólnej platformy politycznej, gwarantującej stabilne i skuteczne rządy w Egipcie. Niemalże od razu pojawiły się istotne różnice pomiędzy liberalną a konserwatywną częścią społeczeństwa, których apogeum stanowity zamach stanu oraz krwawe starcia na ulicach Kairu latem 2013 roku. Atutem prezydenta Sisiego było poparcie polityczne oraz pomoc finansowa ze strony Arabii Saudyjskiej oraz kilku innych państw arabskich z rejonu Zatoki Perskiej. Na tej podstawie można wskazać na istotną rolę czynnika zewnętrznego w procesie przemian politycznych w Egipcie.

Paradoksalnie dobre wyniki makroekonomiczne Egiptu w ostatnim roku rządów Hosni Mubaraka nie przełożyły się na poprawę sytuacji ekonomicznej większości członków egipskiego społeczeństwa. Było wręcz przeciwnie. Egipcjanie wciąż odczuwali skutki międzynarodowego kryzysu finansowego z 2008 roku. Szczególnie trudna była sytuacja młodych ludzi, w tym absolwentów wyższych uczelni. Wysoki poziom bezrobocia oraz relatywnie niskie zarobki uniemożliwiały dalszy rozwój. Równie istotny problem stanowiło rosnące rozwarstwienie społeczne, a także zjawisko klientelizmu. Reżim wspierał posłusznych i lojalnych obywateli, na przykład, poprzez odpowiednią politykę kadrową w ramach armii czy administracji państwowej. Wydarzenia 2011 roku postrzegano zatem nie tylko jako wielką szansę na zmiany polityczne, ale także jako okazję do przeprowadzenia głębokich zmian gospodarczych i społecznych, które z kolei miały się przełożyć na poprawę warunków życia.

Do wybuchu społecznego niezadowolenia w Egipcie przyczynił się także sukces tunezyjskiej opozycji, na co wskazal, między innymi, Jeremy M. Sharp. Samuel Tadros wykazał jednak, że kazus tunezyjski stał się źródłem inspiracji dla Egipcjan dopiero po ucieczce prezydenta Ben Alego z Tunezji. Wcześniejsze wydarzenia, w tym samopodpalenie i śmierć Mohameda Bouazizi, nie spotkały się z większym zainteresowaniem egipskiej opinii publicznej.

\section{Bibliografía}

Abdallah A. H. (2013), Prosecutor general orders Morsi tried for espionage along with Brotherhood leaders, http://www.dailynewsegypt.com/2013/12/18/prosecutor-general-orders-morsi-tried-for-espionage-along-with-brotherhood-leaders/, 30.12.2014.

Achcar G. (2013), The People Want: A Radical Exploration of the Arab Uprising, Berkeley-Los Angeles.

Al-Banna I. M. (2014), Egypt and Revolution, Cairo. 
Al-Sayyid M. K. (2009), Kefaya at a Turning Point, w: Political and Social Protest in Egypt, red. N. S. Hopkins, Cairo.

Amin G. (2011), Egypt in the Era of Hosni Mubarak 1981-2011, Cairo.

Bokhari K., Senzai F. (2013), Political Islam in the Age of Democratization, Basingstoke.

Cambanis T. (2015), Once Upon A Revolution: An Egyptian Story, New York.

Clarke K. (2013), Aish, huriyya, karama insaniyya: Framing and the 2011 Egyptian Uprising, „European Political Science", nr 12.

Drwęski B. (2014), Islam, laickość - islamizm, laicyzm. Kwestia postępu w polityce muzulmańskiej, „As-Salam", nr 2.

Egypt supreme court calls for parliament to be dissolved, http:/www.bbc.com/news/world-middle-east-18439530, 24.12.2014.

El-Mahdi R. (2009), The Democracy Movement: Cycles of Protest, w: Egypt: The Moment of Change, red. R. El-Mahdi, P. Marfleet, London.

El-Naggar A. El-Sayed (2009), Economic Policy: From State Control to Decay and Corruption, w: Egypt: The Moment of Change, red. R. El-Mahdi, P. Marfleet, London.

El-Sisi wins Egypt's presidential race with $96.91 \%$, http://english.ahram.org.eg/NewsContent/1/64/ 102841/Egypt/Politics-/BREAKING-PEC-officially-announces-AbdelFattah-ElSi.aspx. 23.12.2014.

Farah N. R. (2009), Egypt's Political Economy: Power Relations in Development, Cairo.

Ghonim W. (2012), Revolution 2.0. The Power of the People is Greater Than the People in Power: A Memoir, New York.

Ginat R. (1997), Egypt's Incomplete Revolution: Lufti al-Khuli and Nasser's Socialism in the 1960s, London.

Issa Ali Abi (2011), Doktryna Braci Muzulmanów a sytuacja doktrynalno-prawna świata muzulmańskiego, „As-Salam”, $\mathrm{nr} 1$.

Kandil H. (2012), Soldiers, Spies and Statesmen: Egypt's Road to Revolt, New York.

Kazzih W. (2013), Egypt Under Mubarak: A Family Affair, w: Egypt's Tahrir Revolution, red. D. Tschirgi, W. Kazziha, S. F. McMahon, London.

Korany B., El-Mahdi R. (2012), The Protesting Middle East, w: Arab Spring in Egypt: Revolution and Beyond, red. B. Korany, R. El-Mahdi, Cairo.

Lipa M. (2013), Autorytaryzm na arabskim Bliskim Wschodzie. Egipt w latach 1981-2010, Warszawa.

Lipa M. (2014), Polityczne aspekty Arabskiej Wiosny w Egipcie, w: Porewolucyjny Egipt. Wybrane aspekty spoleczne i polityczne, red. P. Niziński, M. Lipa, Kraków.

Marsot A. L. S. (2009), Historia Egiptu. Od podboju arabskiego do czasów wspólczesnych, Warszawa.

Naguib S. (2009), The Muslim Brotherhood. Contradictions and Transformations, w: Political and Social Protest in Egypt, red. N. S. Hopkins, Cairo.

Purat A. (2014), Znaczenie Bractwa Muzulmańskiego w polityce Egiptu oraz w wydarzeniach Arabskiej Wiosny 2011 roku, „Przegląd Politologiczny”, vol. 19, nr 1.

Rutherford B. K. (2008), Egypt After Mubarak: Liberalism, Islam, and Democracy in the Arab World, Princeton.

Schwedler J., King R. (2014), Political Geography, w: The Arab Uprisings Explained: New Contentious Politics in the Middle East, red. M. Lynch, New York.

Sedky A. R. (2013), Cairo Rewind: The First Two Years of Egypt's Revolution 2011-2013, Victoria.

Sen A. K. (2013), Egypt's interim president names leadership, Salafists approve, „The Washington Post", 9.07.

Sharp J. M. (2011), Egypt: the 25 January Revolution and Implications for U.S. Foreign Policy, Washington D.C. 
Sharp J. M. (2012), Egypt: The January 25 Revolution and Implications for US Foreign Policy, w: Tunisia and Egypt: Unrest and Revolution, red. J. C. De Leon, C. R. Jones, New York.

Soliman S. (2012), The Political Economy of Mubarak's Fall, w: Arab Spring in Egypt: Revolution and Beyond, red. B. Korany, R. El-Mahdi, Cairo.

Stacher J. (2012), Adaptable Autocrats: Regime Power in Egypt and Syria, Cairo.

Stępniewska-Holzer B., Holzer J. (2006), Egipt. Stulecie przemian, Warszawa.

Tadros S. (2014), Reflections on the Revolution in Egypt, Stanford.

The Economist: The World in 2015 (2014).

Wejkszner A. (2014), Ewolucja zagrożenia dzihadystycznego a przemiany demokratyczne w państwach Maghrebu, „Przegląd Politologiczny”, vol. 19, nr 1.

Wickham C. R. (2014), The Muslim Brotherhood After Mubarak. What the Brotherhood Is and How It Will Shape the Future, „Foreign Affairs”, http:/www.foreignaffairs.com/articles/67348/ carrie-rosefsky-wickham/the-muslim-brotherhood-after-mubarak, 10.10.2014.

Zahid M. (2012), The Muslim Brotherhood and Egypt's Succession Crisis: The Politics of Liberalisation and Reform in the Middle East, London.

Zdanowski J. (2011), Bliski Wschód 2011: bunt czy rewolucja?, Kraków.

Zdanowski J. (2013), Klasy, elity i klientelizm na muzulmańskim Bliskim Wschodzie, w: Wladza na muzulmańskim Bliskim Wschodzie. Wybrane aspekty, red. J. Zdanowski, Warszawa.

\section{The causes and course of the political transformation in Egypt in 2011-2014}

\section{Summary}

The political crises in Egypt in 2011 and 2013 constituted an essential element in the entire process of socio-political transformations in the Arab states of North Africa and the Middle East. The ousting of the influential President Hosni Mubarak in February 2011 had a special and symbolic meaning for both Egyptians and the citizens of other Arab states. Therefore, the victory of the demonstrators in Tahrir Square was significant in both its domestic and regional dimensions. The Egyptian success provided a clear incentive for the societies of other authoritarian Arab states, such as Syria, Libya and Yemen.

In this context, it is crucial to answer the question of what social, political and economic factors brought about such a rapid political change in Egypt. From the point of view of 2015, is it really true that the ruling elite was replaced, or were the 2011 events largely inspired by circles close to President Mubarak, thereby being only a manifestation of internal competition inside the army and the National Democratic Party belonging to the regime?

Key words: Egypt, Arab Spring, Egyptian revolution, Tahrir Square, Kefaya 